DE DE GRUYTER OPEN
Research Article

$$
\begin{array}{r}
\text { C) } 2018 \text { Milka Elena Escalera Chávez and Celia Cristóbal Hernández. } \\
\text { This is an open access article licensed under the Creative Commons } \\
\text { Attribution-NonCommercial-NoDerivs License } \\
\text { (http://creativecommons.org/licenses/by-nc-nd/3.0/). }
\end{array}
$$

\title{
Small and Medium Size Companies Financial Durability Altman Model Aplication
}

\author{
Dra. Milka Elena Escalera Chávez
}

Universidad Autónoma de San Luis Potosí, México

\author{
Celia Cristóbal Hernández
}

PhD student UCC Business School, Universidad Cristóbal Colón

Doi: 10.2478/mjss-2018-0021

\begin{abstract}
In order to achieve good operation and avoid failure, a prediction analysis of the financial status can help business to plan its commercial activities. The objective of this research is to determine if medium and small companies from Tuxtepec, Oaxaca in Mexico are financially durable. The Altman Z-Score was applied. The sample has 32 Medium and small companies from Tuxtepec, Oaxaca. The results show that $3.1 \%$ of the companies are bankrupt, a $25 \%$ of them are in a gray zone and a $75 \%$ are on a safe zone. The results show that the medium and small companies from Tuxtepec, Oaxaca are financially durable.
\end{abstract}

Keywords: Durability, Failure, Small and medium companies, Altman Z-Score

\section{Introduction}

One of the main concerns that business face, especially in today's environment characterized by a global, dynamic and more competitive economy, is their durability through time in particular medium and small companies; and given the fact that the government recognizes them as a national economy engine that contributes with important percentages to employment as well as to the gross domestic product of the country. This sector tends to drop in Mexico due to bad financial management, $80 \%$ of the companies fail before five years and $90 \%$ before ten years; the lack of cash flow in the small and medium companies was a determining factor for the gross domestic product to decrease from 52 to $34 \%$ in just one decade (Vargas, 2012). Small and medium companies depend primarily on financial stability for their permanence and development, hence, finances are fundamental for any enterprise. The financial status prediction can help an organization to plan its commercial activities so as to have a proper operation and avoid failure.

Argenti (1976) describes corporate failure as the lack of management knowledge of a business, this situation occurs when an enterprise has severe losses from way behind in the past, or when the company declares bankruptcy since it does not have enough money at the time to pay its debts. On that same way, Altman (1968) states that corporate failure happens in areas where the company management has detected some signs such as partial payment to suppliers or failure to fulfill some obligations such as tax payments or social security fare payments, among others but failed to acknowledge it until it all crumbles and bankruptcy is imminent.

Small companies tend to face financial difficulties because they often do not have the 
resources to adapt to the changing conditions of the market. Therefore, is it imperative for them to enhance their finances since problems do not always show up immediately and the impact does not only affect the enterprise in the sense that it will remain for ten years in its credit record, but it also affects support of an economy from a given region and as a consequence there is job losses which causes less consumption and finally, it affects the quality of life of the population. The impact of bankruptcy shows clearly that there is the need to predict bankruptcy in a business.

Therefore, one of the needs this sector has is to measure the financial risk since a correct management of the risk will allow the enterprise to prevent financial insolvency situations, and from this the importance of making studies aimed on the financial area arises as a deficient practice obstacles the rest of the organization operations (Romero, Melgarejo, Vela, 2015).

In many cases, some knowledge in advance is of the outmost importance to avoid failure and this will lead to preserving jobs and give entrepreneurs the chance to generate new dividends which will eventually benefit the entrepreneur as well as society together. It is transcendental to encourage entrepreneurs to take measures from the beginning.

Azhar and Ramesh (2017) proved, based on the Altman Z model, that the majority of companies in India do not have good financial health, thus they point out that there is an urgent need for their administration to examine and reduce the financial difficulty of their companies On the other hand, Maina and Sakwa (2017), while researching companies in Kenya, found that not all companies exhibit good financial health since some of them are in the danger zone according to the Altman Z model.

The small and medium companies must have the tools that allow to measure the financial risk of a company, since a proper management of the risk will allow to prevent financial insolvency situations. One of the most known and reliable models to measure an enterprise insolvency is Altman's Z model, which is based on the statistical technique of multiple differential analysis. Based on the considered studies, we come up with the following question: Are small and medium companies from Tuxtepec, Oaxaca considered financially durable?

This research will bring knowledge to support the research about finances and management in Mexico, with accurate and proper elements for its context. Besides, with the information obtained we can stablish an attitude that enhances the understanding and transcendence of the financial conditions of the medium and small enterprise to drive owners or managers to take the right decisions based on the financial management practice and oriented towards the enterprise growth so a proper development and position are allowed in this important socioeconomic sector in Mexico.

On the other hand, the information obtained will make a practical contribution to develop financial methods and strategies applicable to Mexican small and medium companies in particular and in this way, propel this important sector for the country's economy.

\section{Background}

In different empirical researches, small and medium companies have been appointed as one of the main participants in the economic growth as well as in the job creation of a country.

During the year 2014, there are a little more than four millions micro, small and medium companies classified in the manufacturing, commerce and service sectors. The next table shows the distribution according to size. Based on the results of the National Survey on Productivity and Competitiveness of Micro, Small and Medium Enterprises (ENAPROCE 2015) in Mexico, from the total of existent enterprises in the country during $2014,97.6 \%$ are micro and have the $75.4 \%$ of the total personnel employed, followed by the small companies which represent the $2.0 \%$ and the $13.5 \%$ and the medium ones with $0.4 \%$ and $11.1 \%$ respectively.

On the other hand, the National Institute of Statistics, Geography and Information Technology (INEGI) carries out longitudinal studies inside its researches to determine the main indicators that measure the phenomena associated to active life in business, in this sense Perez (2015) shows us that since many years it has been thought that survival and mortality of businesses have causes that cannot be identified. In this context, INEGI (2014) carried out a retrospective study with the purpose to determine the survival, mortality and years of life of enterprises in the country, according 
to the sector they belong to, size and age. The life expectancy is the average number of years enterprises are expected to survive from the moment they are created.

On a national level the percentage of company's creation is of $28.3 \%$ and mortality is of $22 \%$, this means that approximately 22 out of 100 existent enterprises stopped operating. Regarding life expectancy and survival, the table shows the indicators per economic sector and size, according to age.

Table 1: Survival, death and life expectancy indicators on a national level.

\begin{tabular}{|c|c|c|c|}
\hline Business age & Survival & Deaths & Life expectancy \\
\hline 0 & 100 & 0 & 7.8 \\
\hline 1 & 67 & 33 & 8.2 \\
\hline 5 & 35 & 65 & 9.9 \\
\hline 10 & 25 & 75 & 12.5 \\
\hline 15 & 19 & 81 & 15.7 \\
\hline 20 & 15 & 85 & 19.8 \\
\hline 25 & 11 & 89 & 24.9 \\
\hline
\end{tabular}

Source: own.

In the state of Oaxaca, there is a similar situation, during the last five years there were more business creations than death of these, a $54 \%$ of businesses are created and a $37.8 \%$ die.

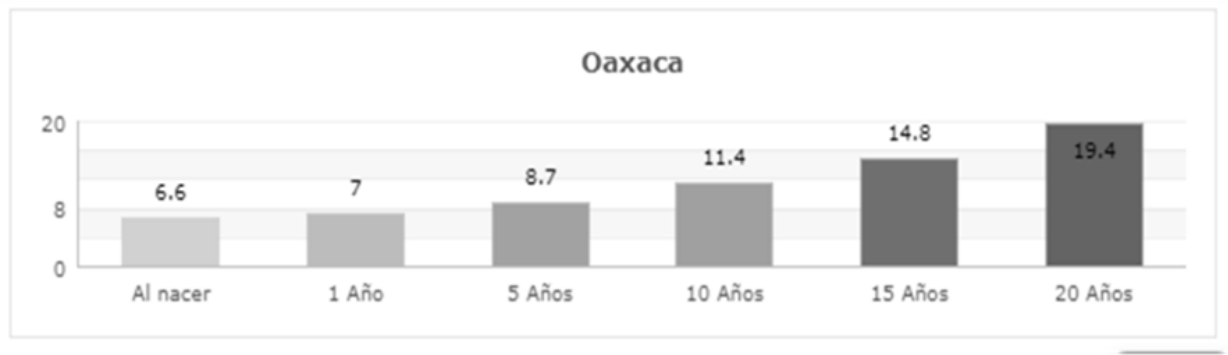

Figure 1: Life expectancy based on the enterprise age.

Source: INEGI, 2014

Life expectancy based on the enterprises age is shown on graphic 1, it is observed that life expectancy increases as the age of the enterprise increases, the opposite happens when the age of the enterprise is less.

\subsection{Hypothesis and objectives}

Based on the previous analysis, we come up with the question and the objective of the research.

$\mathrm{Hi}$ : Medium and Small Enterprises from Tuxtepec, Oaxaca are financially durable enterprises.

To prove the stated hypothesis we come up with the following research objective: determine if the Small and medium companies from Tuxtepec, Oaxaca can be considered financially durable using the Altman model.

\section{Methodology}

In order to prove financial durability in small enterprises, the Altman Z-Score model was analyzed which considers five financial reasons: liquidity, profitability, leverage, solvency and activity as the ones which better predicted bankruptcy in enterprises and allowed to differentiate and identify the 
enterprises with financial difficulties (Rufus, 2003). Altman's final differential function that has been considered more convenient for enterprises by many through the years is the following:

$Z$ score $=1.2 X_{1}+1.4 X_{2}+3.3 X_{3}+0.6 X_{4}+1.0 X_{5}$

Where:

- $\mathrm{X}_{1}$ (working capital/total assets)

- $\mathrm{X}_{2}$ (Retained earnings/total assets)

- $\mathrm{X}_{3}$ (Earnings before interest and taxes/total assets)

- $\mathrm{X}_{4}$ (Market value of equity / book value of total liabilities)

- $\mathrm{X}_{5}$ : (Sales/total assets)

Each one of the indicators were determined and are shown in table 2

Table 2: Codification and description of variables

\begin{tabular}{|l|l|l|}
\hline Code & Variable & Description \\
\hline $\mathrm{X}_{1}$ & Working capital/total & $\begin{array}{l}\text { This relationship provides information about the short-term financial situation } \\
\text { af the company. Higher level of working capital compared to total assets } \\
\text { means higher level of liquidity. }\end{array}$ \\
\hline $\mathrm{X}_{2}$ & $\begin{array}{l}\text { Retained earnings/total } \\
\text { assets }\end{array}$ & $\begin{array}{l}\text { The measure of cumulative profitability that is achieved with this indicator is } \\
\text { sometimes called a "new" ratio because the age of the company is explicitly } \\
\text { considered within it. }\end{array}$ \\
\hline $\mathrm{X}_{3}$ & $\begin{array}{l}\text { Earnings before interest } \\
\text { and taxes/total assets }\end{array}$ & $\begin{array}{l}\text { The reason is independent of factors such as taxes and the effect of financial } \\
\text { leverage that can occur in a company, and is also a measure of the true } \\
\text { productivity of a company justified by the possibility of generating profits from } \\
\text { their assets. }\end{array}$ \\
\hline $\mathrm{X}_{4}$ & $\begin{array}{l}\text { Market value of equity / } \\
\text { book value of total } \\
\text { liabilities }\end{array}$ & $\begin{array}{l}\text { The reason shows how much a company's assets can decline in value } \\
\text { (considering the value of these as a market value of the equity plus the value } \\
\text { of the debts) before the liabilities exceed the assets and the company } \\
\text { becomes insolvent. }\end{array}$ \\
\hline $\mathrm{X}_{5}$ & Sales/total assets & $\begin{array}{l}\text { The ratio measures the ability to generate sales given a certain level of } \\
\text { company assets, for this reason it is considered a measure of the ability of } \\
\text { management to deal with competitive conditions. }\end{array}$ \\
\hline
\end{tabular}

Source: own

One of the variables $\mathrm{X}_{4}$ requires stock capitalization, since small and medium companies are not listed in the stock market the net worth is taken. The probability of bankruptcy of an enterprise will depend on the Altman Z-Score formula result. According to the result, the enterprise could be in a safe zone, gray zone or in a risk zone as shown in table 3.

Table 3: Bankruptcy probability

\begin{tabular}{l|l}
\hline Z-score $>2.99$ & Safe zone, there is no need to worry \\
\hline Z-score $>1.81<2.99$ & Gray zone, the company may go bankrupt in the next two years \\
\hline
\end{tabular}

To apply the model a sample of 32 medium and small enterprises was selected ruled out by a registered accountant for tax purposes for the 2012 and 2013 fiscal years from different sectors and have an accountancy based on the Financial Information Norms.

\section{Results}

On first place, the values obtained for each one of the variables of the 32 enterprises to be studied are shown. After, on table 4 the results of the values of the variables are shown which have been multiplied by the corresponding coefficient of the Z-Score formula proposed by Altman. 
Table 4: Values of the variables from Altman's model.

\begin{tabular}{|c|c|c|c|c|c|}
\hline No. & $X_{1}$ & $\mathrm{X}_{2}$ & $X_{3}$ & $\mathrm{X}_{4}$ & $X_{5}$ \\
\hline 1 & 0.6644 & 0.0744 & 0.1066 & 7.492 & 3.6481 \\
\hline 2 & 0.2854 & 0.2243 & 0.0939 & 0.5094 & 3.7928 \\
\hline 3 & -0.9445 & -1.3459 & 0.0636 & -0.1009 & 16.7188 \\
\hline 4 & -0.5837 & -0.043 & -0.2984 & 0.1571 & 3.7801 \\
\hline 5 & 0.3038 & -0.2994 & 0.5837 & 2.4539 & 4.6251 \\
\hline 6 & -5.459 & -4.6997 & -1.2002 & -0.8439 & 12.3015 \\
\hline 7 & 0.7561 & 0.2065 & 0.1271 & 5.5746 & 1.313 \\
\hline 8 & 0.0353 & 0.0000 & 0.0475 & 0.9546 & 7.9536 \\
\hline 9 & 0.6254 & -0.0052 & -0.0424 & 1.1495 & 1.2719 \\
\hline 10 & 0.0609 & 0.1648 & -0.0531 & 0.6229 & 2.1713 \\
\hline 11 & -0.2763 & 0.0763 & 0.4393 & 0.3451 & 1.1419 \\
\hline 12 & 0.3714 & -0.0829 & -0.0294 & -0.1077 & 3.0188 \\
\hline 13 & 0.7449 & 0.3091 & 0.0894 & 3.4424 & 9.4137 \\
\hline 14 & 0.2191 & 0.4638 & -0.018 & 0.9523 & 6.5595 \\
\hline 15 & 0.3323 & 0.1154 & 0.0691 & 0.3245 & 4.4672 \\
\hline 16 & 0.2772 & 0.0186 & 0.1416 & 0.347 & 1.7103 \\
\hline 17 & -0.2385 & -0.2341 & -0.1023 & -0.1965 & 4.0608 \\
\hline 18 & 0.1679 & 0.5056 & 0.0282 & 1.1607 & 5.8711 \\
\hline 19 & 0.0664 & 0.1401 & 0.0688 & 17.3223 & 0.4078 \\
\hline 20 & 0.794 & 0.791 & 0.165 & 11.438 & 2.205 \\
\hline 21 & 0.994 & 0.347 & 0.201 & 0.999 & 0.306 \\
\hline 22 & 0.067 & -0.325 & 0.003 & 1.917 & 2.902 \\
\hline 23 & -0.039 & -0.273 & -0.096 & 0.986 & 2.967 \\
\hline 24 & 0.406 & 0.432 & 0.120 & 1.136 & 2.547 \\
\hline 25 & -0.193 & -0.318 & -0.086 & 1.118 & 2.766 \\
\hline 26 & 0.066 & 0.227 & 0.113 & 0.667 & 2.753 \\
\hline 27 & 0.288 & 0.007 & 0.040 & 0.450 & 5.505 \\
\hline 28 & 0.547 & 0.000 & 0.048 & 0.955 & 7.954 \\
\hline 29 & 0.238 & 0.308 & 0.045 & 1.447 & 8.857 \\
\hline 30 & 0.418 & 0.104 & 0.457 & 6.318 & 3.334 \\
\hline 31 & 0.366 & 0.579 & 0.028 & 1.936 & 2.763 \\
\hline 32 & -0.086 & -0.361 & -0.007 & 1.230 & 3.363 \\
\hline
\end{tabular}

Source: own

Based on the values from table 4, we get the $Z$ value from each one of the enterprises which are general indexes of a multiple differential function as observed on table 5.

Table 5: Z Scores of small and medium companies

\begin{tabular}{|c|c|c|c|c|c|c|}
\hline No. & $\mathrm{X}_{1}$ & $\mathrm{X}_{2}$ & $\mathrm{X}_{3}$ & $\mathrm{X}_{4}$ & $\mathrm{X}_{5}$ & $\mathrm{Z}$ \\
\hline 1 & 0.797 & 0.104 & 0.35 & 4.50 & 3.64 & 9.39 \\
\hline 2 & 0.342 & 0.314 & 0.31 & 0.31 & 3.79 & 5.06 \\
\hline 3 & -1.133 & -1.884 & 0.21 & -0.06 & 16.70 & 13.83 \\
\hline 4 & -0.700 & -0.060 & -0.98 & 0.09 & 3.78 & 2.13 \\
\hline 5 & 0.365 & -0.419 & 1.93 & 1.47 & 4.62 & 7.96 \\
\hline 6 & -6.551 & -6.580 & -3.96 & -0.51 & 12.29 & -5.31 \\
\hline 7 & 0.907 & 0.289 & 0.42 & 3.34 & 1.31 & 6.27 \\
\hline 8 & 0.042 & 0.000 & 0.16 & 0.57 & 7.95 & 8.72 \\
\hline 9 & 0.750 & -0.007 & -0.14 & 0.69 & 1.27 & 2.56 \\
\hline 10 & 0.073 & 0.231 & -0.18 & 0.37 & 2.17 & 2.67 \\
\hline 11 & -0.332 & 0.107 & 1.45 & 0.21 & 1.14 & 2.57 \\
\hline 12 & 0.446 & -0.116 & -0.10 & -0.06 & 3.02 & 3.18 \\
\hline 13 & 0.894 & 0.433 & 0.30 & 2.07 & 9.40 & 13.09 \\
\hline
\end{tabular}




\begin{tabular}{|c|c|c|c|c|c|c|}
\hline No. & $\mathrm{X}_{1}$ & $\mathrm{X}_{2}$ & $\mathrm{X}_{3}$ & $\mathrm{X}_{4}$ & $\mathrm{X}_{5}$ & $\mathrm{Z}$ \\
\hline 14 & 0.263 & 0.649 & -0.06 & 0.57 & 6.55 & 7.98 \\
\hline 15 & 0.399 & 0.162 & 0.23 & 0.19 & 4.46 & 5.45 \\
\hline 16 & 0.333 & 0.026 & 0.47 & 0.21 & 1.71 & 2.74 \\
\hline 17 & -0.286 & -0.328 & -0.34 & -0.12 & 4.06 & 2.99 \\
\hline 18 & 0.201 & 0.708 & 0.09 & 0.70 & 5.87 & 7.56 \\
\hline 19 & 0.080 & 0.196 & 0.23 & 10.39 & 0.41 & 11.30 \\
\hline 20 & 0.953 & 1.107 & 0.55 & 6.86 & 2.20 & 11.67 \\
\hline 21 & 1.193 & 0.486 & 0.66 & 0.60 & 0.31 & 3.25 \\
\hline 22 & 0.080 & -0.455 & 0.01 & 1.15 & 2.90 & 3.69 \\
\hline 23 & -0.047 & -0.382 & -0.32 & 0.59 & 2.96 & 2.81 \\
\hline 24 & 0.487 & 0.605 & 0.39 & 0.68 & 2.54 & 4.71 \\
\hline 25 & -0.231 & -0.445 & -0.28 & 0.67 & 2.76 & 2.47 \\
\hline 26 & 0.079 & 0.318 & 0.37 & 0.40 & 2.75 & 3.92 \\
\hline 27 & 0.346 & 0.010 & 0.13 & 0.27 & 5.50 & 6.26 \\
\hline 28 & 0.656 & 0.000 & 0.16 & 0.57 & 7.95 & 9.33 \\
\hline 29 & 0.439 & 0.811 & 0.09 & 1.16 & 2.76 & 5.26 \\
\hline 30 & 0.502 & 0.145 & 1.51 & 3.79 & 3.33 & 9.27 \\
\hline 31 & 0.439 & 0.811 & 0.09 & 1.16 & 2.76 & 5.26 \\
\hline 32 & -0.103 & -0.505 & -0.02 & 0.74 & 3.36 & 3.47 \\
\hline
\end{tabular}

Source: own

On graphic 2 the score of the $Z$ values is shown and in the score distribution of each of the enterprises it is observed that there are enterprises with a high score of 13.9 and 13.09 way superior to the limits established by the model, it can also be observed an enterprise with a way low score based on the limits established by the model.

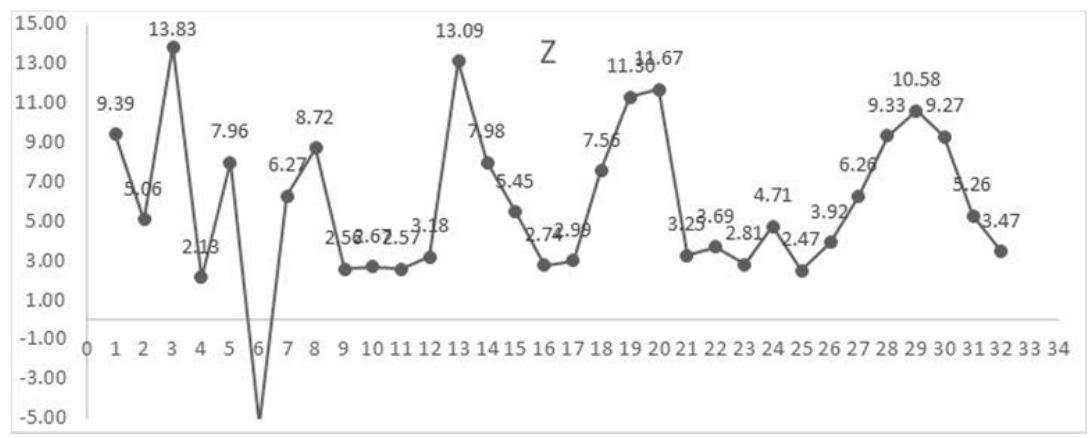

Figure 2: Z-Score scores from the small and medium companies

Based on the cut points proposed by the author (Altman, 2000) it is observed that a $3.1 \%$ of the enterprises have values under $1.81,25 \%$ of the enterprises are among values under 2.99 and a $75 \%$ of the enterprises have values over 2.99 (table 6 ).

Table 6: Bankruptcy probability in small and medium companies

\begin{tabular}{|c|c|c|c|}
\hline$Z$ & Percentage $(\%)$ & bankruptcy probability & Prediction \\
\hline-5.308 & 3.10 & $<1.81$ & Bankruptcy zone \\
\hline $2.125-2.810$ & 21.9 & $>1.81<2.99$ & Gray zone \\
\hline $2.987-13.834$ & 75.0 & $>2.99$ & Safe zone \\
\hline Total & 100 & & \\
\hline
\end{tabular}

Source: own 


\section{Conclusions}

The objective of this research was achieved since it allowed to show evidence that enterprises from Tuxtepec, Oaxaca are durable enterprises by using Altman's model.

If the components of the $Z$ scores are analyzed in detail, these are not very distant from the ones seen on a traditional analysis of financial reasons that are usually seen in finances and accounting introductory courses. In this context, beyond the analysis itself of corporate bankruptcy, the tool can allow students to submerge in an ample discussion of the risks corporations face. If we add the use of tools such as electronic sheets to propel and facilitate its implementation to the previously mentioned, important benefits can also be obtained by improving technical abilities of the students (Cook and Nelson, 1988; Arnold and Earl, 2006).

The simplicity of the models exposed allows an early introduction in courses related to financial analysis and an early detection of problems in companies whether they are small, medium or big, whether they are listed on the stock market and belong to different and varied corporate activities. From here we can conclude that financial problems prevision in enterprises have the imminent benefit to allow the reassignment of financial resources to new and more efficient uses.

\section{References}

Altman, E. (1968). Financial Ratios, Discriminant Analysis and the Prediction of Corporate Bankruptcy. The Journal of Finance, 23: 589-609. DOI: 10.1111/j.1540-6261.1968.tb00843.x.

Altman, E. (2013). Predicting financial distress of companies: Revisiting the Z score and zeta models.in Edward Elgar Publishing (eds) Handbook of Research Methods and Applications in Empirical Finance, 428455.DOI:10.4337/9780857936097.00027

Argenti, J. (1976). Corporate planning and Corporate Collapse. Long Range Planning, 9(6): 12-17. DOI: 10.1016/0024-6301(76)90006.

Arnold, T. \& Earl, J. (2006). Applying Altman's Z-Score in the Classroom. Journal of Financial Education, 32: 98-103.

Azhar, Syed and Ramesh, B., Predicting Financial Insolvency of Listed Power Generation/Distribution Companies in India Using Z-Score (December 14, 2017). IOSR Journal of Business and Management (IOSR-JBM) (2017). Available at SSRN: https://ssrn.com/abstract=3087896

Cook, R. \&. Nelson, J. (1988). A Conspectus of Business Failure Forecasting, in Small Business Institute Director's Association (SBIDA) 1988:205-212.

Economies: A Case of Listed Companies on the Ghana. Journal of Applied Finance \& Banking, 7 (4), 79-92.

Maina, F. \& Sakwa, M. (2017). Understanding financial distress among listed firms in nairobi stock exchange: a quantitative. Approach using the z-score multi-discriminant financial analysis model. University of Agriculture and Technology, Nairobi, Kenya

Oduro, R. \&Amoh, M. (2007). A Model to Predict Corporate Failure in the Developing

Romero, F., Melgarejo, Z. \& Vera-Colina, M. (2015). Business failure of small and medium enterprises in Colombia. Suma de negocios 6.13:29-41. https://doi.org/10.1016/j.sumneg.2015.08.003.

Rufus, R. (2003).Financial ratios: Use, predictive power and the Z-Score. The Valuation Examiner, 14-17.

Vargas, I. (2012). El fracaso acecha a pymes mexicanas. Expansión aliado con CNN. Recuperado de http://expansion.mx/emprendedores/2012/04/05/el-fracaso-acecha-a-pymes-mexicanas. 